\title{
BRUNA E A GALINHA D'ANGOLA: UMA PROPOSTA DE VALORIZAÇÃO DA CULTURA AFRICANA NA EDUCAÇÃO INFANTIL ATRAVÉS DA LITERATURA
}

Sylvia Soares de Souza ${ }^{\mathrm{i}}$

\begin{abstract}
Resumo: Este artigo é um recorte de minha dissertação intitulada: Abioye, Bruna e Cora; Uma proposta de reeducação das relações raciais na literatura Infantil (SOUZA, 2019) na qual analiso três obras literárias com protagonistas negras como propostas de reeducação das relações raciais na educação infantil. Para este trabalho, abordaremos especificamente a obra Bruna e a Galinha D'Angola (ALMEIDA, 2012) que tematiza a cultura africana. A investigação se dá em diálogo com a Lei 10.639/03, assim como, com as Diretrizes Curriculares Nacionais para a Educação Infantil (2010). Destaco, também, os referenciais teóricos de interseccionalidade dos feminismos negros e decoloniais, problematizando, raça, gênero e classe tanto na literatura, quanto na educação infantil e no mercado editorial.
\end{abstract}

Palavras-chave: Reeducação das relações raciais, Cultura africana, Literatura, Educação infantil.

\begin{abstract}
This article is an excerpt from my dissertation entitled: Abioye, Bruna and Cora; A proposal for the re-education of race relations in Children's literature (SOUZA, 2019) in which I analyze three literary works with black protagonists as proposals for the re-education of race relations in early childhood education. For this work, we will specifically address the work Bruna and Galinha D'Angola (ALMEIDA, 2012) that focuses on African culture. The investigation takes place in dialogue with Law 10.639 / 03, as well as with the National Curriculum Guidelines for Early Childhood Education (2010). I also highlight the theoretical references of intersectionality of black and decolonial feminisms, problematizing race, gender and class both in literature, as in early childhood education and in the publishing market.
\end{abstract}

Keywords: Reeducation of race relations, African culture, Literature, Early childhood education.

\section{Introdução}

O presente texto é um fragmento de minha dissertação intitulada: Abioye, Bruna e Cora: uma proposta de reeducação das relações raciais na literatura infantil (SOUZA, 2019), na qual analisei três obras literárias que trouxessem personagens negras como protagonistas.

Um dos critérios para o desenvolvimento da pesquisa foi selecionar exclusivamente obras literárias publicadas por editoras voltadas para a temática étnico-racial negra. Neste sentido, é importante ressaltar a importância de reconhecer a literatura negro-brasileira (FELISBERTO, 2012) como instrumento de valorização das meninas negras, em especial, na educação infantil. 
Para este percurso, mergulhei-me em minhas escritas de si, conceito utilizado por Conceição Evaristo (2005) que lança um novo olhar às mulheres negras, visibilizando seus protagonismos através da escrita. Assim, utilizei a estratégia da escritora para problematizar a subjetividade da criança negra na literatura infantil.

Cabe ressaltar que tal movimento se deu por meio da enunciação de meu lugar como mulher negra e professora de educação básica no âmbito da educação infantil. Declará-lo é importante, porque, assim como Djamila Ribeiro nos fala, "É urgente a ressignificação das identidades seja ela de raça, gênero, classe, com o objetivo de possibilitar voz e visibilidade a sujeitos considerados implícitos dentro da normatização hegemônica” (RIBEIRO, 2017, p. 43).

Desde a promulgação da Lei 10.639/03, a respeito da obrigatoriedade do ensino de história e cultura africana e afro-brasileira no ensino, houve o crescimento de publicações de obras literárias infantis com a temática étnico-racial negra. Também as Diretrizes Curriculares Nacionais para a Educação das Relações Étnico-Raciais e para o Ensino de História e Cultura Afro-brasileira e Africana (BRASIL, 2004) endossam produções literárias que resgatem os valores de uma comunidade cuja participação foi decisiva na construção da nação brasileira.

Ambos os avanços, nascidos das reivindicações do Movimento Negro (MNU), refletem não só a busca por uma educação antirracista que contemple as diferentes matrizes formadoras de nossa sociedade (PEREIRA, 2012), como denunciam o "mito da democracia racial" desmistificando a ideia de que não exista discriminação racial na infância.

Entretanto, ao observar repertórios de obras literárias infantis, oriundos de diversos espaços escolares, constatamos que no Brasil a literatura canônica é derivada das experiências das classes altas. Isto posto, evidencia-se que as produções e narrativas literárias perpassam por uma lógica eurocêntrica. Para Regina Dalcastagnè, (2008) a invisibilidade da população negra é um fato comprovado na literatura brasileira. Em diálogo com a autora, Maria Cristina Gouvea (2005) demonstrou que a literatura destinada a crianças no Brasil produziu personagens negros estereotipados, a partir de referências culturais etnocêntricas.

Por outro lado, o trabalho voltado para a valorização da cultura afro-brasileira nos convida a refletir sobre o perfil das narrativas oferecidas às crianças de diferentes etnias no contexto escolar. Para isso, faz-se necessário o olhar atento de professores e professoras de educação infantil para observar o que tais obras têm oferecido como possibilidades de trabalho com a reeducação das relações raciais. 
Nesta perspectiva, investigar como a literatura tem se posicionado com relação à identidade racial na infância é uma etapa necessária para que a criança desde os primeiros anos possa se reconhecer como sujeito no espaço escolar. Para isto, é imprescindível tecer um diálogo honesto, problematizando as questões de raça e gênero e classe tanto na educação infantil, como no mercado editorial. Em face de tais necessidades, dialogo com Fernanda Felisberto (2011) a respeito do perfil das produções literárias. A autora procura definir a literatura de acordo com o corpus de trabalho que a constitui. Ou seja, ao observar a construção das obras literárias, faz-se necessário identificar quais interseções elas oferecem com a cultura étnico-racial negra.

Diante de tamanha finalidade, há editoras dedicadas a publicações de obras literárias que possam contribuir para a modificação de ideias pré-concebidas sobre pessoas negras no Brasilii $^{i}$. Com relação ao público infantil, as obras nascidas destas editoras apresentam como proposta gerar referências positivas para crianças negras, auxiliando-as na construção de sua identidade. Temas como estética, afetividade e cultura africana têm sido constantemente explorados em enredos e histórias infantis com personagens negras.

Dessa maneira, o contato com essas narrativas visa possibilitar que a criança negra seja visibilizada em suas necessidades, uma vez que as histórias infantis costumam ser eficazes na potencialização das práticas pedagógicas. Nessa direção, Bruna e a Galinha D’Angola (Almeida, 2012) foi uma das obras literárias elencadas para análise por valorizar a cultura africana em sua narrativa.

A escolha deste tema justifica-se pela necessidade de tecer debates a este respeito no currículo escolar. O referido livro lança mão de lendas de Orixás e religiões de matrizes africanas na narrativa. A personagem Nanã, por exemplo, faz referência a um Orixá do Candombléiii. Essa discussão será importante, porque, embora, a Lei 10.639/03 oriente o ensino de história e cultura afro-brasileira e africana no currículo escolar, ainda se evidencia uma dificuldade em incorporar esses temas nas práticas pedagógicas com maior profundidade.

Acontece que o apagamento das contribuições de homens e mulheres negras em nossa cultura distanciou a relação entre a escola e as temáticas africanas. Dessa forma, observa-se a incipiente abordagem destes temas na educação infantil, bem como, a carência de obras literárias correspondentes a estes assuntos na prática educativa. E, quando essa representatividade existe, o desconforto manifestado pela comunidade escolar diante destes temas compromete uma efetiva prática de reeducação das relações raciais. 
Também é importante ressaltar que, por vezes, as lendas e demais elementos africanos são consideravelmente estigmatizados e, por consequência, evitados na educação infantil. E, à medida que ignoramos que a cultura africana é preponderante ao desenvolvimento do país, nos distanciamos da consciência de que tratar da cultura brasileira é tratar de uma cultura multifacetada.

Tais problemas são resultados da colonialidade que rodeia produções intelectuais, manifestações culturais, vozes e saberes, mantendo determinadas vozes em lugares silenciados estruturalmente. Isso explica o porquê de a herança africana encarar tantos embates para garantir direitos e ter o respeito da sociedade brasileira. No caso das religiões de matrizes africanas, em especial, a situação adquire tamanha proporção a ponto de materializar episódios de violência, preconceitos, racismo e intolerância religiosa, dentro e fora do espaço escolar. No Brasil, as denúncias de intolerância religiosa aumentaram 56\% em $2019^{\text {iv }}$.

Essas questões sinalizam os desafios que o espaço escolar enfrenta para trabalhar a cultura africana em seus currículos. Ao analisar Bruna e a Galinha D’Angola, espera-se que surjam debates importantes a serem explorados nas práticas pedagógicas. Reconhecendo ainda que a narrativa da obra literária analisada toca em assuntos referentes à raça, etnia, gênero, cultura e religiosidade, é importantíssimo destacar que os debates feministas decoloniais ajudam a ressignificar tais saberes.

Sendo assim, o decorrer dessa pesquisa aponta que as editoras que priorizam a temática étnico-racial negra têm se dedicado, consideravelmente, a publicações infantis que abarquem a cultura africana. Tratam-se de narrativas envolventes, ricas em aspectos culturais, visando promover um efetivo contato de crianças com as lendas, mitos e histórias orais. No caso de Bruna e a Galinha D'Angola, é a personagem Bruna que, na condição de protagonista, destaca a identidade negra e as heranças culturais, oriundas dos povos africanos. Dessa forma, é importante observar como a referida obra literária aborda a cultura africana no espaço escolar.

\section{Sobre a importância de fazer outras perguntas}

Como proposta de método, elaborei uma ficha de análise destacando questões a serem investigadas nos livros selecionados. Tais fichas foram uma das etapas vivenciadas por Teresa Colomer (2003) para pesquisar obras com narrativas infantis e juvenis. Organizadas por quatro 
eixos, a autora selecionou os critérios que mais estavam mais adequados à sua proposta de análise.

Assim como Colomer, também busquei critérios que dialogassem com a minha pesquisa, e motivada pelo método da teórica feminista Mari Matsuda (1991), optei por "fazer outras perguntas" para a elaboração das fichas. O conceito desenvolvido pela autora articula raça e gênero, para visibilizar os marcadores de racismo e violência de gênero, nos diversos contextos sociais. Vejamos abaixo, a conceituação do método de Mari Matsuda:

Muitas vezes, uma condição pode ser identificada, por exemplo, como produto óbvio do racismo, porém, mais poderia ser revelado se, como rotina, fossem colocadas as seguintes perguntas: "Onde está o sexismo nisso? Qual a sua dimensão de classe? Onde está o heterossexismo?". E a fim de ampliar ainda mais tais questionamentos, poder-se-ia perguntar: De que forma esse problema é matizado pelo regionalismo? Pelas consequências históricas do colonialismo? (MATSUDA, 1991, p. 1184)

Mari Matsuda define que fazer perguntas nos ajuda a encontrar os sinais de discriminação racial, mesmo em contextos nos quais o racismo é velado e passa despercebido. Com base nas contribuições da autora, elaborei uma ficha de análise para conduzir-me na investigação das obras literárias.

\section{Ficha de análise}

- Qual é o título da obra literária?;

- Qual é a editora?;

- Quem são os autores ou autoras?;

- Em que ano a obra foi publicada?;

- Resumo da Obra;

- Quais são os temas contemplados na obra?;

- Qual a ilustração da Capa?;

- Quem exerce a função de protagonista na obra literária?;

- Como o feminino é trabalhado através das personagens da obra literária?. 


\section{Livro: Bruna e a Galinha d'Angola}

Bruna era uma menina que se sentia muito sozinha. Quando estava muito triste, ia para a casa de sua avó Nanã, que chegara de um país muito distante, $e$ pedia-lhe para contar-lhe histórias de sua terra natal.

(ALMEIDA, 2012, p.01)

Conheci Bruna e a Galinha D’Angola através do trabalho da Timbuktu-livraria ambulante. Gosto de narrar como adquiri cada uma das obras literárias selecionadas para análise, pois sei que nestes relatos existem encontros e vivências que dão todo o significado ao trabalho desenvolvido no texto da dissertação. Com relação ao livro Bruna e a Galinha $D^{\prime}$ Angola, creio que o fato de tê-lo conhecido dentro de uma das ações realizadas pela Timbuktu não foi por acaso.

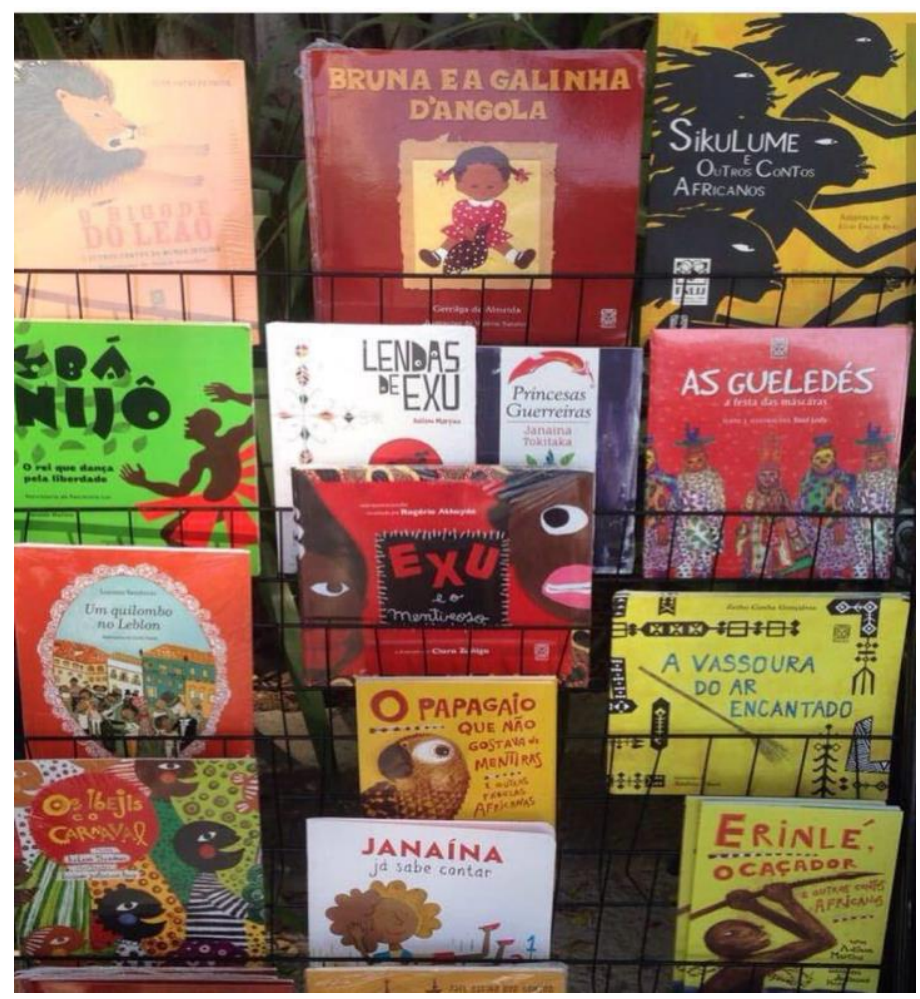

Figura 1: Registro de stand da Livraria Timbuktu na UFRJ, onde conheci a obra: Bruna e a Galinha D'Angola.

Fonte: Página da Livraria Timbuktu

Revista Interinstitucional Artes de Educar. Rio de Janeiro, V. 7, N. 1 - pág. 82-101 janeiro-abril de 2021: "Pedagogias Vitais: Corpo, Desejo e Educação" DOI: 10.12957/riae.2021.55288 
O nome da livraria fez-me recordar que esse foi o nome da cidade da primeira universidade do mundo, classificada como patrimônio mundial da Organização das Nações Unidas para a Educação, a Ciência e a Cultura (UNESCO) nascida em Timbuktu, localizada no Oeste Africano do Mali. Os manuscritos da Universidade com mais de 800 anos foram resgatados pelos livreiros da cidade. Além dos valiosos documentos históricos, os pergaminhos e manuscritos comprovavam que as histórias dos povos africanos também eram difundidas pela escrita e não somente de forma oral. Em suma, a universidade da cidade de Timbuktu resgatou patrimônios da cultura africana.

São justamente esses princípios que a história do livro Bruna e a Galinha D’Angola aborda consigo na narrativa. As vivências da personagem na história conectam-se ao universo mítico africano, que, neste caso, está representado pela galinha d’Angola e sua relação com a criação do universo. Assim sendo, através dos elementos da narrativa, a obra contempla a ancestralidade, a oralidade e a importância de respeitar as tradições e diferenças culturais de um povo.

Pensar nessas estratégias é essencial para a criação de efetivas formas de enfrentamento do racismo nos contextos educacional e social. A educação infantil constitui-se como espaço amplo para vivências que despertem possibilidades de diálogo. Portanto, é possível potencializar a experiência das crianças sobre a diversidade étnico-racial negra, utilizando diversas linguagens, em especial, os livros infantis. Dessa forma, as perguntas direcionadas para Bruna e a Galinha D'Angola auxiliarão a elucidar caminhos, para a obtenção destas experiências.

\section{O universo de Bruna: título da obra, tema, autoria e editora}

Bruna e a Galinha D’Angola foi publicado em 2012 pela Editora Pallas. A obra traz uma narrativa alimentada por valores civilizatórios afro-brasileiros (TRINDADE, 2010) práticas culturais africanas, repertórios orais, tradições e demais elementos que compõem o patrimônio da cultura africana e afro-brasileira.

A autoria da obra fica a cargo de Gercilga de Almeida. Ao buscar informações sobre a escritora, foi possível observar que suas subjetividades estão conectadas às construções da narrativa. Gercilga de Almeida é pedagoga, professora de filosofia e conhecedora profunda da 
mitologia negra. Todos esses lugares aos quais a autora pertence deram significado à referida obra, a ponto de tornar-se o primeiro livro infantil que tematiza o universo mítico africano.

A história nos apresenta Bruna, uma linda menina que estava triste, porque não tinha amigos e, muitas vezes, sentia-se sozinha. A personagem Nanã é a figura que auxilia Bruna a superar estas inquietações ao acalentar-lhe por meio da prática das histórias orais e das lendas sobre sua terra natal. Sobre isso, Conceição Evaristo afirma que "a história oral é uma opção estética da escrita a uma textualidade comprometida com a afirmação cultural afrodescendente, por meio da enunciação de uma memória social” (EVARISTO, 2003, p.19) Nesse sentido, Bruna e a Galinha D’Angola vai ao encontro de Conceição Evaristo, ao trazer as histórias orais contadas pela personagem Nanã para enriquecer a narrativa.

A relação de Nanã e Bruna simboliza um dos temas mais presentes ao longo da história, que é a ancestralidade, marca eminentemente africana, pela qual as pessoas mais velhas partilham suas histórias de vida e saberes com as crianças. Afinal, é praticamente impossível construir um futuro sem conhecer o passado e acionar a nossa ancestralidade.

Por outro lado, a relação de Nanã com Bruna também expressa narrativas em que uma personagem negra seja inserida em um contexto familiar provido de afetos. Dessa forma, o tema também evoca a importância do contexto familiar para as crianças, em especial, para as crianças negras, para que, assim, elas encontrem acolhimento para a construção de suas vivências.

Em Vivendo de Amor, bell hooks ${ }^{\mathrm{v}}$ relata a importância de os sujeitos negros resgatarem a afetividade. Embora, em determinados momentos a autora se refira à intimidade, compromisso e paixão, também há trechos em que entram em cena os laços afetivos com os entes queridos. O processo escravocrata provocava separações e dores inestimáveis aos sujeitos, à medida que eram distanciados das pessoas que amavam, como os filhos, mães, pais e avós. Como forma de sobrevivência, essas pessoas continham e reprimiam seus sentimentos. Vejamos um trecho de bell hooks para exemplificar esse processo.

Tradicionalmente, as famílias do Sul do país ensinavam as crianças ainda pequenas que era importante reprimir as emoções. Normalmente, as crianças aprendiam a não chorar quando eram espancadas. Expressar os sentimentos poderia significar uma punição ainda maior. Os pais as avisaram: "- Não quero ver nem uma lágrima". E se a criança chorava, ameaçavam: "- Se não parar, vou te dar mais uma razão para chorar." Como é possível diferenciar esse comportamento daquele do senhor de engenho que espancava seu escravo sem permitir que ele experimentasse qualquer forma de consolo, ou mesmo que tivesse um espaço para expressar sua dor? E se tantas crianças negras aprenderam desde cedo que expressar as emoções é sinal de fraqueza, como 
poderiam estar abertas para amar? Muitos negros têm passado essa ideia de geração a geração: se nos deixarmos levar e render pelas emoções, estaremos comprometendo nossa sobrevivência. Eles acreditam que o amor diminui nossa capacidade de desenvolver uma personalidade sólida. (hooks, 2017, p. 52)

Em diálogo com bell hooks, observo que a obra Bruna e a Galinha D’Angola tematiza bem essa questão, despertando crianças negras sobre a importância dos afetos e possibilidades de acolhimento no contexto familiar. Nesse sentido, é válido explorar a narrativa para aproveitar as possibilidades de participação da família e da criança.

Outro tema que evoca possibilidades de trabalho são as religiões de matrizes africanas. Embora, Nanã seja apresentada no livro inicialmente como a avó de Bruna, a personagem faz referência a uma Orixá do Candomblé. Situação semelhante acontece na passagem na qual é narrada a lenda de Òsún para falar sobre a criação do mundo. "Conta a lenda de minha aldeia africana que Òsún era uma menina que se sentia só. Para lhe fazer companhia resolveu criar o que ela chamava de 'o seu povo'. Foi, assim, que surgiu Conquém, ou melhor, a galinha D'Angola deste pano" (ALMEIDA, 2012, p. 01).

A figura de Òsún é uma entidade espiritual cultuada tanto na Umbanda como no Candomblé. De acordo com as lendas dos Orixás, foi Òsún quem desceu à terra para deixar o mundo pronto para a humanidade. Além disso, ela representa o poder, a sabedoria e a força feminina. Dessa forma, através das lendas das quais Bruna e a Galinha D'Angola faz uso ao longo da narrativa, fica evidente que os temas referentes à religiosidade e cultura africana acionam o universo infantil de maneira lúdica e com bastante sutileza. Tais estratégias tornam possível promover um ambiente de diálogo e respeito às diferenças já na educação infantil. Assim sendo, considero que Bruna e a Galinha D'Angola seja um material rico em:

Narrativas ficcionais, fábulas e contos que atribuem aos personagens qualidades e poderes diversos e que se relacionam com o comportamento humano, atitudes e valores culturais, a crenças e saberes de diversos grupos e povos. Como dito anteriormente, tanto as fábulas como os contos africanos têm algo de extraordinário e de sobrenatural e visam advertir, instruir e orientar os modos de agir, de acordo um uma ordem moral, própria das culturas que criaram e preservaram essas narrativas. (BRASIL, 2014, p. 68)

Dessa forma, espera-se que a obra efetive possibilidades para que na educação infantil crianças possam conviver com diferentes campos de conhecimento para além das normativas 


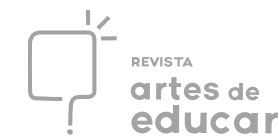

eurocêntricas. A ênfase na cultura africana como aspecto a ser trabalhado no currículo escolar é um movimento essencial para a obtenção da ação antirracista na educação infantil.

Em contrapartida, o direito às diversas manifestações culturais e religiosas diz respeito à construção das subjetividades de crianças com diferentes etnias, para que elas possam expressar suas trajetórias de vida, em um viés de respeito e valorização. Inerentes a tais objetivos, vejamos o que propõe as ilustrações de Bruna e a Galinha D'Angola.

\section{Eis a menina de vestido vermelho e a misteriosa galinha d'angola. $O$ que apresenta a capa de Bruna e a Galinha d'Angola?}

A capa do livro foi impressa em papel cartão, ao passo que as demais páginas foram confeccionadas com papel couchê. No caso de Bruna e a Galinha D'Angola, a escolha do papel cartão para a capa certamente se deu por ser um material de alta gramatura, o que faz com que se ampliem as condições de durabilidade do livro. O destaque também se dá para o aspecto brilhoso da capa e a presença de cores atrativas para a apresentação da obra literária.

Sobre a representação de Bruna na capa do livro, a menina surge posicionada dentro do quadro amarelo cujo aspecto rememora o papiro, planta encontrada nos rios da África e do Oriente Médio utilizada como matéria prima do papel. Além disso, há uma relação de contraste estabelecida pelas cores amarela e vermelha que conferem destaque à ilustração da personagem principal da narrativa.

Para Modesto Farina (2011), “as cores atuam sobre a nossa afetividade produzindo diferentes sensações". As palavras do autor fazem todo o sentido na rotina da educação infantil, pois crianças, mesmo quando bem pequenas, utilizam as cores para produzir grafismos, conferindo a estes significados próprios. Até mesmo nas primeiras pinceladas com tinta guache e pintura com os dedos manifestadas na educação infantil são as cores que acompanham as crianças na expressão de suas ideias.

Sabendo disso, o mercado editorial investe neste recurso para a produção de livros voltados para o público infantil, visando à aproximação com as crianças. Quanto menor a faixa etária, mais as ilustrações são coloridas. Em muitos casos, as ilustrações acabam tendo maior relevância para a criança do que os enunciados escritos. Exatamente, por isso, a sobreposição de cores confere destaque para a personagem Bruna na capa do livro. 


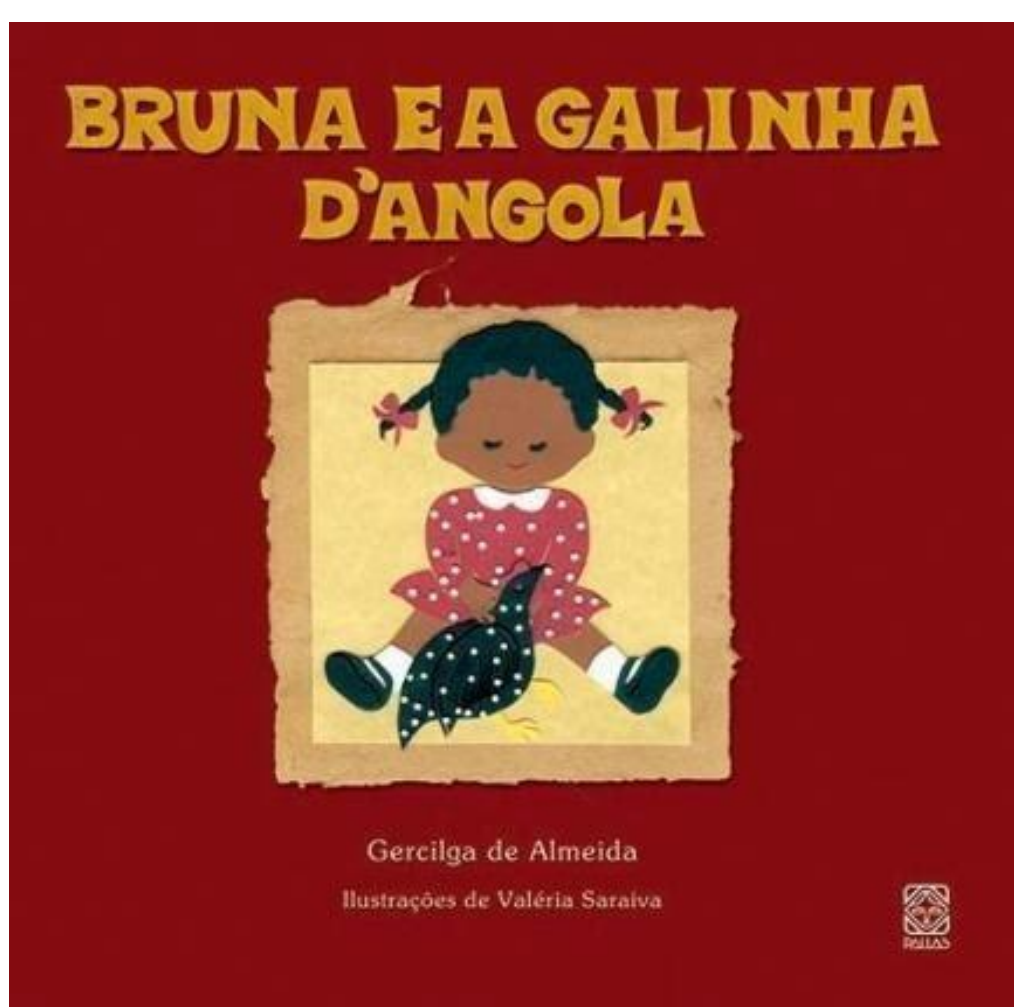

Figura 2: Capa do Livro: Bruna e a Galinha D’Angola. Fonte: Livro Bruna e a Galinha D’Angola. Editora Pallas.

Como Bruna é a única personagem ilustrada na capa, juntamente com a galinha D’Angola, evidencia-se que sua posição é de protagonista da narrativa. Além disso, ao identificar Bruna na capa do livro, no processo de leitura, a criança é voltada para a personagem concebendo, dessa forma, a ideia de que é ela quem conduzirá as ações da narrativa. Tal concepção reafirma Bruna como sujeito central da história.

Ao descrever a ilustração da personagem, é possível constatar que Bruna aparece de olhos fechados, sorrindo e sentada com as pernas entreabertas, onde a galinha D’Angola se aconchega. As feições ilustradas no rosto da personagem são singelas, possibilitando um processo de identificação entre crianças. Ainda sobre Bruna, é importante destacar a tamanha delicadeza pela qual seus traços são delineados. Além disso, a imagem da menina utilizando um lindo vestido vermelho, sapatos de boneca e laços em cada uma de suas tranças corrobora a perspectiva de ser uma personagem cercada de cuidado, carinho e afetos.

A caracterização positiva de Bruna, à qual me refiro acima, é um aspecto importante a ser considerado por serem exemplos de ilustrações que não correspondem a representações estereotipadas de meninas negras nos livros infantis, que costumam mostrar personagens negras de forma pejorativa, sem se preocupar com a possibilidade de causar desconforto às crianças 
negras. Ao contrário, é totalmente possível que as crianças na educação infantil vivam experiências positivas através da ilustração dessa personagem.

Já com relação às ilustrações das demais páginas do livro, é possível perceber que elas atuam como recurso para auxiliar as crianças na compreensão da narrativa. É importante levar em conta que por se tratar de uma história que aborda a cultura africana, pode ser que alguns elementos apresentados durante a leitura não sejam de conhecimento da criança. A ilustração da galinha d’Angola é um destes exemplos, pois, embora a galinha seja um animal popular no Brasil, esta galinha possui características específicas que, neste caso, são as penas pretas e as pintas brancas.

As ilustrações não só fidelizam esta informação como tornam possível identificar a analogia com as pintas da galinha no vestido de Bruna. No travesseiro da personagem, na passagem que ela sonha com a galinha Conquém e, até mesmo, na ilustração que aponta o ninho onde a galinha D’Angola protegia e chocava os seus ovos.

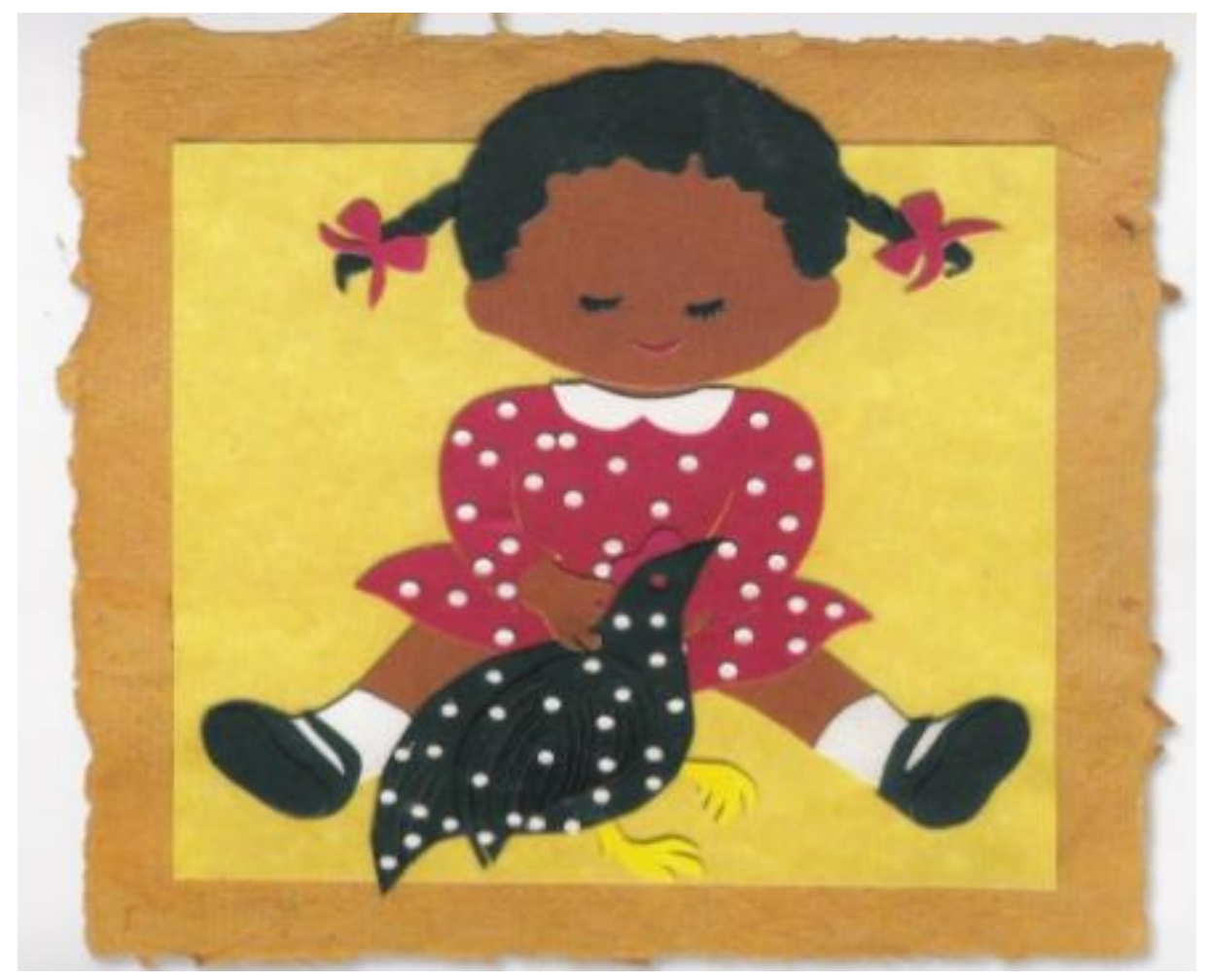

Figura 3 - Bruna ilustrada com vestido de pintas brancas em alusão à Galinha D’Angola que está em seu colo. Fonte: Livro Bruna e a Galinha D’Angola. 


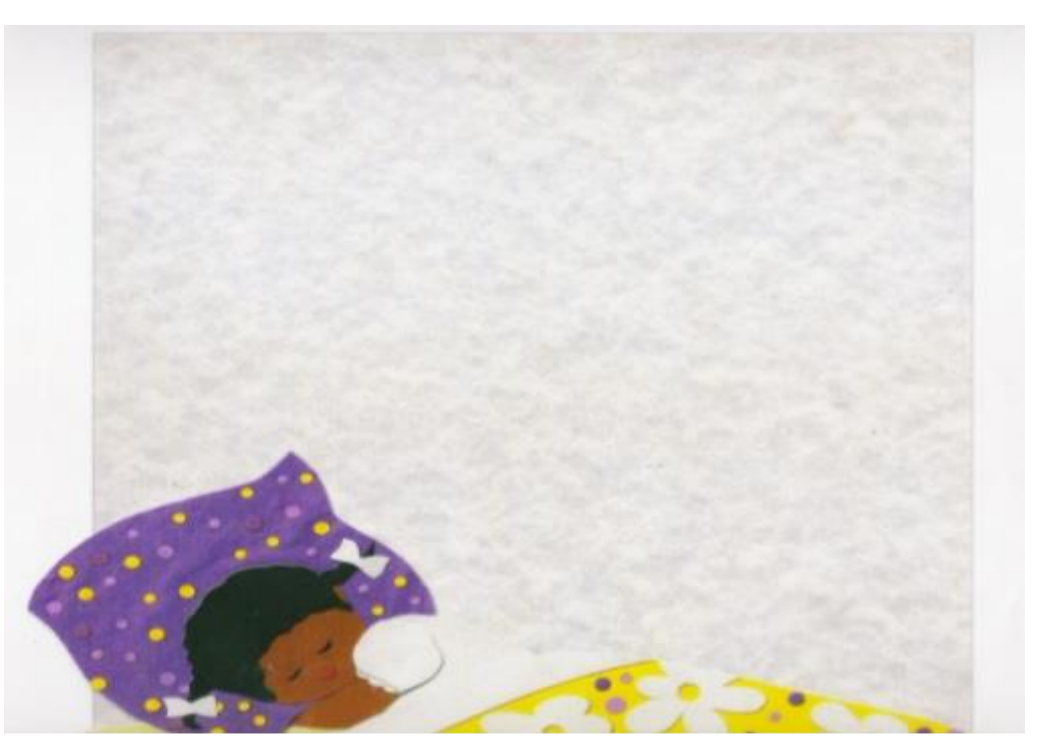

Figura 4 - Ilustração do trecho em que a Bruna sonha com a galinha Conquém. Fonte: Livro Bruna e a Galinha D’Angola.

O mesmo ocorre em relação ao panôs, tecido no qual a história da galinha estava estampada e que foram trazidos por Nanã da África, sua terra natal. Umas das ilustrações mostra o panô em que Nanã conta a história da galinha d’Angola. Em outro momento, Bruna pede ao tio, que era um bom oleiro, para ensinar-lhe a fazer esculturas de barro, para modelar a galinha Conquém. Nessa passagem, também é possível identificar que a galinha de barro está sobreposta em um pano de fundo que se assemelha ao tecido, como conexão aos panôs narrados na história.

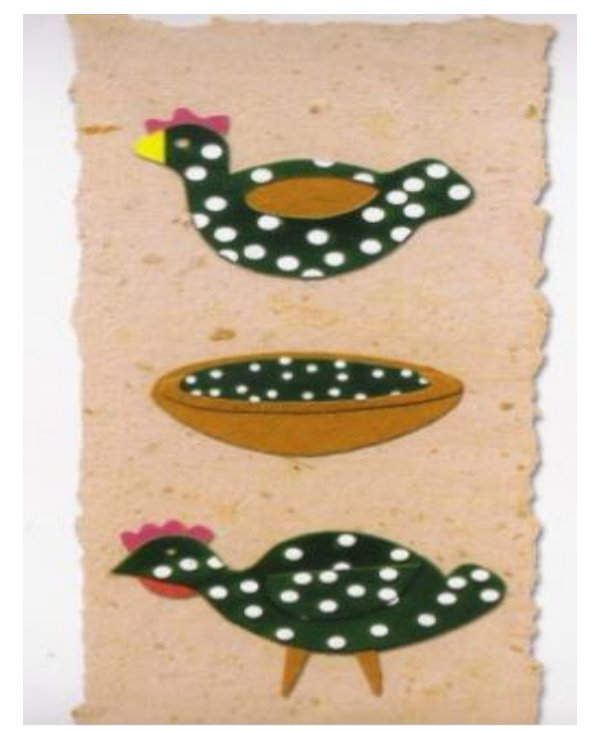

Figura 5: Galinha Conquém de Barro. Fonte: Bruna e a Galinha D’Angola. 
Em suma, é possível observar que a forma como a ilustração da capa e as das demais páginas vão ao encontro do que temos defendido neste trabalho sobre a importância de que livros infantis possam oferecer mecanismos eficazes para a promoção da igualdade racial e de gênero. Afinal, a identidade é construída a partir da relação do indivíduo com o meio que ele está inserido.

\section{O protagonismo em Bruna e a Galinha d’Angola}

Ao fixar-nos na leitura de Bruna e a Galinha d'Angola, é possível observar diversos elementos que apontam a personagem Bruna como protagonista da narrativa. O primeiro a ser destacado é o título da obra literária, que é composto pelo nome da personagem. $\mathrm{O}$ fato de a história se chamar Bruna e a Galinha D’Angola não só aponta para as crianças que terão contato com a história, que é para Bruna que a narrativa está direcionada, como potencializa a dimensão identitária da personagem.

A preocupação de intitular a narrativa com o nome de Bruna demonstra a intenção em valorizá-la como uma personagem que tem um nome, identidade e características próprias. Conforme Maria Oliveira nos alerta, é relevante lembrar que muitas obras cujos personagens eram negros apresentavam atitudes depreciativas, dentre as quais narrar sujeitos que sequer possuíam nomes próprios. Em contrapartida, o livro Bruna e a Galinha D’Angola se mostra alinhado à valorização étnico-racial à medida que as personagens da narrativa são reforçadas como sujeitas visíveis, dotadas de identidade e pertencentes a uma organização cultural.

Outra característica referente ao protagonismo da personagem Bruna está no modo como ela exerce suas ações. A relação entre Bruna e Nanã é o pontapé inicial para a valorização da ancestralidade e da cultura africana. Mesmo assim, observamos que é Bruna quem estabelece uma postura potencialmente ativa, estando à frente de todos os acontecimentos decorrentes da história. Para começar, é ela quem vai ao encontro de Nanã para ouvir as lendas e histórias contadas por sua avó. Também, podemos notar o protagonismo de suas ações, quando ela busca o tio para aprender a produzir galinhas de barro. Nesse sentido, a atuação de Bruna como protagonista na narrativa evoca a ideia de quanto mais se sabe sobre a devida trajetória, mais potente se torna a apropriação de nossos saberes e de sujeitos da própria história. 


\section{Como o feminino é abordado em Bruna e Galinha d'Angola?}

A narrativa de Bruna e a Galinha D’Angola é constituída predominantemente por personagens femininas: Bruna, Nanã, a Galinha D’Angola, Òsún e as amigas que Bruna conhece após ser presenteada com a galinha, quando faz aniversário. O único personagem masculino é o tio de Bruna, que a ensina a fazer galinhas de barro. Contudo, não há maiores informações sobre sua identidade, a não ser que ele é um bom oleiro.

Em diálogo com a preponderância feminina da narrativa, é interessante analisar as construções apresentadas através de tais características. Sobre isso, destaco a relevância da personagem Nanã. De acordo com a história, cada vez que Bruna está triste, é à Nanã que recorre para sanar sua tristeza, ouvindo as histórias orais contadas por sua avó. Bruna sabe que as histórias orais lhe conferem o pertencimento com sua cultura e ancestralidade. Sendo assim, Nanã traz a compreensão de que Bruna não está sozinha.

Por outro lado, o ritual de compartilhar histórias, realizado entre a avó e a neta, traz para a Nanã a figura de uma mulher forte, dotada de sabedoria, que transmite seus conhecimentos para empoderar Bruna com relação ao seu pertencimento étnico-racial. Nessa direção, ambas as personagens representam concepções de feminino associadas à valorização das narrativas oriundas da tradição oral africana. Em contrapartida, Nanã e Bruna também assumem a ressignificação da importância da figura da avó e da mãe na vida da criança.

$\mathrm{Na}$ cultura brasileira, a identificação com a figura de Nanã ocorre com facilidade, se pensarmos nas memórias que cada sujeito tem tecidas no seio familiar. Em geral, a figura mais velha estabelece um elo conectando os familiares através dos encontros e afetos. As confraternizações de família, conversas, celebrações de aniversário e os álbuns de fotografias são rituais que significam as memórias de um grupo e os conscientizam que fazem parte da mesma trajetória. Essa ação faz-se visível na história, quando Bruna é presenteada com a galinha d'Angola, por sua avó. Concebido como um ritual de passagem, o aniversário da menina é um marco para a descoberta da ancestralidade enquanto porto seguro, no qual ela poderá fincar as raízes culturais.

Tais aspectos podem ser evidenciados ao debruçar-nos sobre o trabalho de Franciene da Silva (2018). A autora narra que, para as culturas das matrizes africanas, os idosos são os sábios da comunidade e seu papel é fundamental para legitimar a identidade de um grupo. De acordo com Franciene da Silva: 
Para as culturas de matrizes africanas, os idosos são os sábios da comunidade, aqueles que possuem o conhecimento e podem garantir a continuidade do grupo. Desse modo, quando um ancião ou anciã parte para o outro plano, não é esquecido e, muitas vezes, torna-se ainda mais presente do que quando estava vivo. Depois de sua morte, seus descendentes fazem perpetuar os seus saberes, que são fundamentais para que o grupo permaneça coeso e cada vez mais forte. (SILVA, 2018, p. 67)

O fragmento da escrita de Franciene Silva elucida sobre as estratégias lançadas por Nanã para que Bruna tenha contato com a sua cultura. A este exemplo, diversas passagens da história condizem com esta afirmação. Uma delas é o baú que Nanã perdera e que foi encontrado por Bruna e as amigas que acabara de conquistar. Dentro dele, estava o panô desenhado com a história de Òsún. Nanã guardou aquele baú como quem guarda um tesouro precioso. Nele, havia histórias orais pertencentes ao seu povo. Ao encontrá-lo, Nanã o transmite como herança à sua descendência, nesse caso, representada pela figura de Bruna. Em suma, evidencia-se que a personagem de Nanã representa as figuras ancestrais, cuja influência atua de maneira direta na formação da identidade de seus descendentes. Na forma como elas se relacionam com o mundo e consigo mesmas.

\section{Considerações finais}

A criança, desde os seus primeiros anos de vida, necessita reconhecer-se como sujeito no espaço escolar. Para isso, ela deve ter acesso a elementos referentes ao seu pertencimento. Sendo assim, é compromisso da escola contemplar as pluralidades étnicas de meninos e meninas, incorporando suas narrativas nas práticas pedagógicas e currículos escolares.

Nessa perspectiva, a literatura apresenta-se com possibilidade de trabalho, uma vez que provoca na criança relações, interações e apropriações favoráveis ao seu desenvolvimento (CORSINO, 2014). Através das publicações infantis é possível aproximar-se de diversas áreas de conhecimento, entre elas, questões relacionadas à raça e gênero e em constante diálogo com o contexto infantil.

Por outro lado, é praticamente impossível obter uma efetiva prática da reeducação das relações raciais, através das obras literárias, sem antes reconhecer que a literatura está atrelada a um projeto de nação (COUTINHO, 2002) o qual que, ao favorecer o pensamento eurocêntrico, produziu narrativas em que a população negra é retratada de maneira inferiorizada. Nessa 


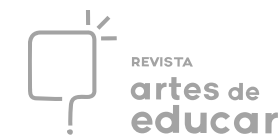

direção, destacamos que a cultura e as religiões das matrizes africanas foram afetadas por esse processo de maneira profunda, por meio de um doloroso movimento de marginalização e intolerância que perdura até hoje, dentro e fora do espaço escolar.

Assumir essa realidade nos permite, não somente, tecer um diálogo honesto sobre questões de raça, gênero e classe em nosso cotidiano e, em especial, no espaço escolar, como problematizar sobre estas questões a partir das experiências distintas (COLLINS, 2006).

Com base neste diálogo, é possível afirmar que Bruna e a Galinha D’Angola é uma obra literária que materializa algumas destas experiências distintas. A trajetória da autora e a sensibilidade pela qual o tema é tratado ao longo da narrativa e a riqueza de elementos culturais lançados de maneira positiva, contribui para um corpus literário de autorrepresentação. E nessa direção, as editoras que se dedicam especialmente à publicação de obras voltadas para a temática étnico-racial negra têm se destacado por assumir como responsabilidade dar novo sentido às histórias individuais e coletivas, bem como à valorização da herança africana.

Nesse sentido, é importantíssimo que obras literárias como Bruna e a Galinha D’Angola estejam cada vez mais presentes no repertório escolar da educação infantil e sejam visibilizadas como um caminho para a prática antirracista na escola.

\section{REFERÊNCIAS}

ALMEIDA, G. Bruna e a Galinha D’Angola. Rio de Janeiro: Pallas, 2012.

AMARO, Vagner. [Entrevista cedida à] Editora Malê. Disponível em: http://www.letras.ufmg.br/literafro/editoras/1034-editora-male-entrevista-com-vagner-amaro. Acesso em 19 abr. 2019.

ARAÚJO, D. Literatura Infanto-juvenil e Política Educacional: Estratégias de Racialização no Programa Nacional de Biblioteca da Escola (PNBE). Tese (Doutorado em Educação). Universidade Federal do Paraná (UFPR), 2015.

BRASIL. Lei das Diretrizes e Bases da Educação Nacional. 1996.

Lei 10639 de 9 de janeiro de 2003.

Ministério da Educação. Diretrizes Curriculares Nacionais para a Educação das Relações étnico-raciais para o ensino de História e Cultura Afro-brasileira e Africana. 2004.

Ministério da Educação. Diretrizes Curriculares Nacionais para a Educação Infantil. Brasília: MEC/SEB, 2010.

Revista Interinstitucional Artes de Educar. Rio de Janeiro, V. 7, N. 1 - pág. 82-101 janeiro-abril de 2021: "Pedagogias Vitais: Corpo, Desejo e Educação" DOI: 10.12957/riae.2021.55288 
infantil. 2014.

Ministério da Educação. História e cultura africana e afro-brasileira na educação

- Ministério da Educação. Literatura na Educação Infantil, acervos, espaços e

mediações. $2014 . \quad$ Disponível em: http://portal.mec.gov.br/index.php?option=com_docman\&view=download\&alias=36771seminario-ebook-versao-impressao-pdf\&category_slug=marco-2016-pdf\&Itemid=30192

Ministério da Educação. Parâmetros Curriculares Nacionais - Pluralidade cultural. Disponível em: http://portal.mec.gov.br/seb/arquivos/pdf/pluralidade.pdf. Acesso em: 9/3/2019

COELHO, N. N. Literatura infantil: teoria, análise e didática. Rio de Janeiro: Editora Moderna, 2000.

COLLINS, P. Aprendendo com a outsider within*: a significação sociológica do pensamento feminista negro. Revista Sociedade e Estado: Brasília. 2016

COLOMER, T. A formação de Leitor Literário: narrativa infantil e juvenil atual. Editora Global: São Paulo. 2003.

CORSINO, P. Leitura Literária na escola e produção de sentido. 2014.

Disponível em http://www.uece.br/endipe2014/ebooks/livro1/310\%20LEITURA\%20LITER\%C3\%81RIA\%20NA\%20ESCOLA\%20E\%20PRODU\%C3\%87\% C3\%83O\%20DE\%20SENTIDO.pdf. Acesso em: 05 maio 2019

COUTINHO, E. Discurso literário e construção da identidade brasileira. Légua \& meia: Revista de literatura e diversidade cultural. Feira de Santana: UEFS, n 1, 2002, p. 54-63.

DALCASTAGNÈ, R. Entre silêncios e estereótipos: relações raciais na literatura brasileira contemporânea. Estudos de Literatura Brasileira Contemporânea, nº 31. Brasília, janeirojunho de 2008, p. 87-110.

EVARISTO, C. Ponciá Vicêncio. Belo Horizonte: Mazza, 2003.

Da representação à Auto-representação da mulher negra na Literatura Brasileira. Revista Palmares, set-2005, 2005. Disponível em: http://www.palmares.gov.br/sites/000/2/download/52\%20a\%2057.pdf. Acesso em: 25 abr. 2018

FARINA, M. Psicodinâmica das cores em comunicação. Editora Blucher: São Paulo, 2011.

FELISBERTO, F. Escrevivências na diáspora: escritoras negras, produção editorial e suas escolhas afetivas, uma leitura de Carolina Maria de Jesus, Conceição Evaristo, Maya Angelou e Zora Beale Hurston. 2011. Disponível em: https://bdtd.ibict.br/vufind/Record/UERJ_89c204c7ba61de7a1c1bba95423618b3. Acesso em: 10 abr. 2019. 
GOUVEA, M. C. Imagem do negro na Literatura infantil brasileira: análise historiográfica. Educação e Pesquisa, São Paulo, v. 31, n. 1, p. 79-91, jan./abr. 2005.

hooks, b. Vivendo de amor. Disponível em: https://www.geledes.org.br/vivendo-de-amor/. Acesso em 07 fev. 2019.

MARTINS, C. Nanã: a senhora dos primórdios. Rio de Janeiro: Editora Pallas, 2011.

MATSUDA, M. Beside My Sister, Facing the Enemy: Legal Theory out of Coalition. Stanford Law Review, v. 43, n. 6, jul., 1991, pp. 1183-1192. Disponível em: https://www.scribd.com/document/313908659/MATSUDA-Mari-Besides-My-Sister-Facingthe-Enemy. Acesso em: 12 fev. 2019.

PEREIRA, A. Por uma autêntica democracia racial: os movimentos negros nas escolas e nos currículos de história. Revista História Hoje. v. 1, no 1, p. 111-128 - 2012. Disponível em: https://rhhj.anpuh.org/RHHJ/article/view/21/25. Acesso em: 25 abr. 2019.

RIBEIRO, D. O que é lugar de fala? Djamila Ribeiro. Belo Horizonte (MG): Letramento: Justificando, 2017.

SILVA, F. A presença da ancestralidade em narrativas de Conceição Evaristo e Mia Couto. Cadernos CESPUC de Pesquisa Série Ensaios, n. 32, p. 78-92, 12 abr. 2018.

TRINDADE, A. Os valores civilizatórios e a Educação Infantil: uma contribuição afrobrasileira. In: BRANDÃO, A. P.; TRINDADE, A. L. (org.). Saberes e Fazeres, vol.5: Modos de Brincar. Rio de Janeiro: Fundação Roberto Marinho, 2010.

\footnotetext{
${ }^{\text {i }}$ Mestra em Educação pelo Programa de Pós-graduação em Educação na Universidade Federal do Rio de Janeiro (UFRJ). Pertence ao quadro de professores EBTT do Instituto Benjamin Constant (IBC), como professora de Educação Infantil atuando no ensino especializado de crianças com deficiência visual. Integra o Grupo de estudos e pesquisas "Intelectuais Negras - UFRJ" e "Ciência ao Alcance das mãos - IBC". E-mail: sylvia.ssouza@ hotmail.com. Rio de Janeiro. Brasil. ORCID: https://orcid.org/0000-0001-7111-8856

ii Editora Malê. Entrevista com Vagner Amaro. Disponível em: http://www.letras.ufmg.br/literafro/editoras/1034editora-male-entrevista-com-vagner-amaro. Acesso em 19 abr. 2019.

iii MARTINS, Cléo. Nanã: a senhora dos primórdios. Rio de Janeiro: Pallas, 2011. Nanã, a aiabá (orixá feminino) dos primórdios, é a senhora das águas paradas, dos pântanos e lagoas, das areias movediças e das poças de água. É a senhora da lama, por excelência: a síntese de elementos primordiais, podendo ser definida como 'início, meio e fim'. Nanã se apresenta na forma de uma senhora idosa e muito lúcida, sábia, poderosa e que tem conhecimento do próprio poder. Ela é justa e solitária, forte e corajosa e, mais do que tudo, dotada de um caráter ambíguo: é fonte da vida por excelência, mas também é a senhora de Icu, a morte. Senhora da ambiguidade que não engana. É considerada İyá Nlá - a grande mãe da criação - epíteto dividido com Odudua e Iemanjá - e Ayaba l'arè, a grande rainha da justiça, o que a faz tão poderosa quanto Xangô, o padroeiro da justiça. É a senhora do equilíbrio, da sabedoria, do conhecimento, da experiência. Quando as pessoas querem ter discernimento, pedem a Nanã que lhes clareie as mentes.
}

Revista Interinstitucional Artes de Educar. Rio de Janeiro, V. 7, N. 1 - pág. 82-101 janeiro-abril de 2021: "Pedagogias Vitais: Corpo, Desejo e Educação" DOI: 10.12957/riae.2021.55288 
iv Disponível em: https://www.brasildefato.com.br/2020/01/21/denuncias-de-intolerancia-religiosa-aumentaram56-no-brasil-em-2019/Acesso em: 01 jun. 2020.

${ }^{v}$ bell hooks é um pseudônimo de Glória Jean Watkins, escritora norte-americada nascida em 25 de setembro de 1952, no Kentuchy - EUA. O apelido que ela escolheu para assinar suas obras é uma homenagem aos sobrenomes da mãe e da avó. O nome é assim mesmo, grafado com letras minúsculas. A justificativa é encontrada em uma das frases escrita pela autora: "O mais importante em meus livros e a substância e não quem eu sou". 